\title{
Penyelesaian atas Sertipikat Tanah Ganda Menurut Peraturan Pemerintah Nomor 24 Tahun 1997 Tentang Pendaftaran Tanah (Studi Putusan: Putusan Mahkamah Agung Nomor 1537 K/PDT/2018)
}

\author{
Vanesia Hendrika Elvina \\ (Mahasiswa Program S1 Fakultas Hukum Universitas Tarumanagara) \\ (E-mail: vaneelvina88@gmail.com)
}

\section{Dr. Hasni, S.H, M.H.}

(Corresponding Author)

(Dosen Fakultas Hukum Universitas Tarumanagara. Meraih Sarjana Hukum pada Fakultas Hukum Universitas Krisnadwipayana, Magister Hukum pada Fakultas Hukum Universitas Indonesia)

(E-mail: hasni@fh.untar.ac.id)

\begin{abstract}
The purpose of implementing land registration is to provide legal certainty and legal protection. The Agrarian Law that is used in Indonesia adheres to a negative system that is tied to a positive system. The land registration activity for the first time produced proof of rights, in the form of certificates as a means of proof of land rights. Certificate as a strong proof of rights means that physical data and juridical data in a certificate have the strength of evidence and must be accepted as true information, as long as it is not proven otherwise with other evidence in the form of certificates or other certificates. In Subari's case, there was a double land certificate in the same plot of land. Subari has the ownership of land rights that is got from his parents and from purchasing with two buffaloes. But, there are other people who dominate the land that is belong to Subari and they also have the certificate to proof their ownership of the land rights. Settlement of multiple land certificates can be done through the Court, to obtain legal certainty that the certificate of ownership of land rights which has stronger evidence is based on evidence. The district court ruled that ownership of land rights belonged to Subari, and this decision was reinforced by high court and a Supreme Court.
\end{abstract}

Keywords: Agrarian law, land registration, land rights, certificate

\section{PENDAHULUAN}

\section{A. Latar Belakang}


Negara Republik Indonesia merupakan negara kepulauan yang mempunyai banyak kekayaan alam yang terkandung di dalamnya dan merupakan suatu karunia dari Tuhan Yang Maha Esa kepada seluruh rakyat Indonesia dan oleh karena itu, sudah semestinya pemanfaatan kekayaan alam tersebut ditujukan untuk mencapai sebesar-besarnya kemakmuran seluruh rakyat Indonesia. Ketentuan dalam Pasal 33 Ayat (3) Undang Undang Dasar Negara Republik Indonesia 1945 (selanjutnya disebut UUD 1945) mengatur bahwa kemakmuran rakyat menjadi tujuan utama dalam pemanfaatan fungsi bumi, air, dan ruang angkasa serta kekayaan alam yang terkandung di dalamnya.

Seiring dengan berjalannya waktu, kebutuhan manusia akan tanah semakin meningkat mengikuti arus laku pertumbuhan ekonomi dan penduduk yang tidak diimbangi dengan persediaan tanah yang terbatas. Ketidakseimbangan tersebut telah menimbulkan persoalan dari banyak segi bukan masalah tanah saja tetapi masalah yuridis, ekonomi, sosial dan politik yang disebabkan karena tanah merupakan kebutuhan yang sangat mendasar dan menempati kedudukan yang sangat penting dan strategis dalam kehidupan dan pembangunan di masa sekarang dan masa yang akan datang.

Pada tanggal 24 September 1960, Undang-Undang Nomor 5 Tahun 1960 tentang Peraturan Dasar Pokok-Pokok Agraria yang lebih dikenal dengan nama singkatan resminya Undang-Undang Pokok Agraria, disebut UUPA disahkan oleh Presiden Republik Indonesia Soekarno dan diundangkan dalam Lembaran Negara Republik Indonesia Nomor 104 Tahun 1960. Dengan mulai berlakunya UUPA sehingga terjadi perubahan yang fundamental pada Hukum Agraria di Indonesia, terutama hukum di bidang pertanahan. ${ }^{1)}$

Salah satu tujuan diundangkannya UUPA adalah meletakkan dasar-dasar untuk memberikan kepastian hukum mengenai hak-hak atas tanah bagi rakyat

\footnotetext{
${ }^{1)}$ Boedi Harsono, Hukum Agraria Indonesia: Sejarah Pembentukan Undang-Undang Pokok Agraria, Isi, dan Pelaksanaannya, Cetakan ke-4, (Jakarta: Universitas Trisakti, 2018), hal.1.
} 
seluruhnya. Pemberian jaminan kepastian hukum mengenai hak-hak atas tanah bagi keseluruhan rakyat Indonesia dapat terwujud melalui dua upaya yakni sebagai berikut:

1. Tersedianya perangkat hukum yang tertulis, lengkap dan jelas yang dilaksanakan secara konsisten sesuai dengan jiwa dan ketentuan-ketentuannya; dan

2. Penyelenggaraan pendaftaran tanah yang memungkinkan bagi pemegang hak atas tanah untuk dengan mudah membuktikan hak atas tanah yang dikuasainya, dan bagi pihak yang berkepentingan, seperti calon pembeli dan calon kreditor, untuk memperoleh keterangan yang diperlukan mengenai tanah menjadi objek perbuatan hukum yang akan dilakukan, serta bagi Pemerintah untuk melaksanakan kebijaksanaan pertanahan. ${ }^{2)}$

Ketentuan mengenai pendaftaran tanah diatur dengan Peraturan Pemerintah Nomor 24 Tahun 1997 (selanjutnya disebut "PP 24/1997”) yang menggantikan Peraturan Pemerintah No. 10 Tahun 1961 (selanjutnya disebut "PP 10/1961”) sehingga PP 10/1961 tersebut dinyatakan tidak berlaku. PP 10/1961 dan PP/1997 tersebut merupakan bentuk pelaksanaan pendaftaran tanah dalam rangka rechtscadaster (pendaftaran tanah) yang bertujuan memberikan kepastian hukum dan perlindungan hukum kepada pemegang hak atas tanah, dengan alat bukti yang dihasilkan pada akhir proses pendaftaran tanah tersebut berupa Buku Tanah dan sertipikat tanah yang terdiri dari Salinan Buku Tanah dan Surat Ukur. ${ }^{3)}$

PP 24/1997 secara tegas menyebutkan bahwa instansi Pemerintah yang menyelenggarakan pendaftaran tanah di seluruh wilayah Republik Indonesia menurut Pasal 5 adalah Badan Pertanahan Nasional (BPN), selanjutnya dalam Pasal 6 Ayat (1) nya ditegaskan bahwa dalam rangka penyelenggaraan pendaftaran

\footnotetext{
${ }^{2)}$ Urip Santoso, Pendaftaran dan Peralihan Hak atas Tanah, Cetakan ke-1. (Jakarta: Kencana, 2010), hal.2.

3) Arie S. Hutagalung, Tebaran Pemikiran Seputar Masalah Hukum Tanah, Lembaga Pemberdayaan Hukum Indonesia, (Jakarta: 2005), hal.81.
} 
tanah tersebut, tugas pelaksanaannya dilakukan oleh Kepala Kantor Pertanahan Kabupaten/ Kota ${ }^{4)}$ yang sekarang menjadi Kementerian Agraria dan Tata Ruang (ATR) yang diatur dalam Peraturan Presiden Nomor 17 Tahun 2015 tentang Kementerian Agraria dan Tata Ruang (yang selanjutnya disebut "Perpres Nomor 17 Tahun 2015") yang menyatakan bahwa Kementerian Agraria dan Tata Ruang mempunyai tugas untuk menyelenggarakan urusan pemerintahan dalam bidang agraria/pertanahan dan tata ruang untuk membantu Presiden dalam menyelenggarakan pemerintahan Negara.

Kegiatan pendaftaran tanah untuk pertama kalinya menghasilkan surat tanda bukti hak, berupa sertipikat sebagai alat pembuktian hak atas tanah. Pengertian sertipikat diatur dalam Pasal 32 Ayat (1) PP 24/1997 tentang Pendaftaran Tanah, yakni bahwa Sertipikat merupakan surat tanda bukti atas hak yang berlaku sebagai alat pembuktian yang kuat. Dalam sertipikat sendiri terdapat data fisik dan yuridis yang termuat didalamnya. Sertipikat sebagai alat pembuktian yang kuat sepanjang data fisik dan yuridis tersebut sesuai dengan data yang terdapat dalam surat ukur dan buku tanah hak yang bersangkutan.

Sertipikat tanah diterbitkan oleh Kantor Pertanahan Kabupaten/ Kota. Penerbitan sertipikat dimaksudkan supaya pemegang hak atas tanah dapat dengan mudah untuk membuktikan haknya dan oleh karena itu sertipikat merupakan alat pembuktian yang kuat, sebagaimana dinyatakan dalam Pasal 19 UUPA. Sertipikat sebagai surat tanda bukti hak yang bersifat mutlak dengan memenuhi unsur-unsur secara kumulatif, yaitu:

1. Sertipikat diterbitkan secara sah atas nama orang atau badan hukum;

2. Tanah diperoleh dengan itikad baik;

3. Tanah dikuasai secara nyata menguasainya;

4. Dalam jangka waktu 5 tahun sejak diterbitkannya sertipikat, tidak ada pihak yang mengajukan keberatan secara tertulis kepada pemegang sertipikat dan

\footnotetext{
4) Urip Santoso, Op. Cit., hal.23.
} 
Kepala Kantor Pertanahan Kabupaten/ Kota setempat ataupun tidak mengajukan gugatan ke Pengadilan mengenai penguasaan tanah atau penerbitan sertipikat. ${ }^{5)}$

Dari ketentuan di atas dapat kita ketahui bahwa sertipikat tanah mempunyai arti dan peranan penting bagi pemegang yang bersangkutan, juga berfungsi sebagai alat bukti hak atas tanah. Pemilik tanah mempunyai alat bukti kuat sehingga akan lebih mudah untuk membuktikan bahwa tanah tersebut adalah miliknya. Demikian pula pihak lain yang akan berkepentingan terhadap tanah bersangkutan akan lebih mudah memperoleh keterangan yang dapat dipercaya.

Pada kenyataannya masih sering terjadinya sengketa tanah yang memberikan kebingungan dalam masyarakat. Banyaknya sengketa tanah yang terjadi saat ini disebabkan karena berbagai macam persoalan masyarakat yang salah satunya yaitu sengketa mengenai sertipikat hak atas tanah. Berdasarkan fakta-fakta yang ada di masyarakat, Sertipikat Hak Atas Tanah masih belum sepenuhnya memberikan jaminan kepastian hukum dan perlindungan hukum kepada pemilik Hak Atas Tanah. Sertipikat Hak Atas Tanah masih menghadapi kemungkinan adanya gugatan dari pihak lain yang juga merasa memiliki Hak Atas Tanah tersebut, sehingga apabila dapat dibuktikan secara hukum bahwa ia adalah pemilik sebenarnya maka Sertipikat Hak Atas Tanah dapat dibatalkan. ${ }^{6)}$

Tujuan pelaksanaan pendaftaran tanah adalah untuk memberikan jaminan kepastian hukum dan perlindungan hukum. Namun dalam realitanya pemegang Sertipikat Hak Atas Tanah belum merasa aman akan kepastian haknya dikarenakan seringkali muncul banyaknya sengketa yang membatalkan sertipikat melalui Lembaga Peradilan. Sertipikat Hak Atas Tanah sendiri sering mengalami pembatalan disebabkan adanya gugatan dari pihak lain yang juga memiliki Sertipikat Hak Atas Tanah, yang dengan kata lain dapat dikatakan bahwa pada

\footnotetext{
5) Ibid, hal.45-46.

6) Boedi Harsono, (selanjutnya disebut Boedi Harsono I), Hukum Agraria Indonesia (Himpunan Peraturan-Peraturan Hukum Tanah), Cetakan Kelimabelas, (Jakarta: Djambatan, 2002), hal.398.
} 
suatu tanah terdapat lebih dari satu Sertipikat Hak Atas Tanah sedangkan pendaftaran tanah sendiri diadakan oleh BPN.

Seperti contoh yakni kasus yang terjadi di daerah Grobogan, Jawa Tengah, yang terjadi antara salah seorang bernama Subari yang mempunyai Sertipikat Hak Milik (SHM) atas tanah menggugat beberapa pihak yang salah seorang diantaranya bernama Mukhlisin yang mengaku juga memiliki SHM dan BPN sebagai Turut Tergugat. Subari mengaku mendapatkan tanah tersebut yang berasal dari pembelian dengan 2 (dua) ekor kerbau, sedangkan Mukhlisin bersama pihakpihak lain mengaku mendapatkan tanah tersebut sebagai warisan dari orang tuanya. Sengketa ini kemudian diajukan ke Pengadilan Negeri Purwodadi dengan hasil putusan nomor:14/Pdt.G/2017/PN PWD yang menyatakan bahwa SHM milik penggugat adalah sah secara hukum dan SHM milik Mukhlisin dan tergugat lainnya adalah cacat hukum dan batal demi hukum. Putusan nomor: 14/Pdt.G/2017/PN PWD diperkuat oleh putusan Pengadilan Tinggi nomor: 345/Pdt/2017/PT SMG dan putusan Mahkamah Agung nomor: 1537 K/Pdt/2018.

Berdasarkan latar belakang tersebut di atas, Penulis tertarik untuk mendalami dan menuangkan kasus tersebut dalam proposal penulisan skripsi dengan judul: "Penyelesaian Atas Sertipikat Tanah Ganda Menurut Peraturan Pemerintah Nomor 24 Tahun 1997 Tentang Pendaftaran Tanah (Studi Putusan: Putusan Mahkamah Agung Nomor 1537 K/PDT/2018)”.

\section{B. Perumusan Masalah}

Berdasarkan uraian latar belakang di atas maka permasalahan yang hendak Penulis ajukan adalah: Bagaimana penyelesaian atas sertipikat tanah ganda menurut Peraturan Pemerintah Nomor 24 Tahun 1997 tentang Pendaftaran Tanah (Studi Putusan: Putusan Mahkamah Agung Nomor 1537 K/PDT/2018)? 


\section{Metode Penelitian}

Penelitian dilakukan guna menemukan sumber-sumber yang diperlukan untuk dapat memprediksi apa yang akan dilakukan sehingga dapat diketahui apa saja tindakan-tindakan yang dapat diambil. ${ }^{7)}$ Selain itu, penting bagi setiap karya ilmiah untuk mencantumkan metode penelitian, karena bila naskah tidak dilengkapi dengan metode penelitian, naskah akan dengan mudah ditolak dan dipertanyakan isinya. ${ }^{8)}$

Penelitian hukum adalah suatu proses yang digunakan untuk menemukan suatu aturan hukum, prinsip-prinsip hukum, maupun doktrin-doktrin hukum untuk menjawab suatu permasalahan hukum yang dihadapi. ${ }^{9)}$ Demikian dalam penelitian ini Penulis menentukan metode-metode yang akan digunakan, yakni sebagai berikut:

1. Jenis Penelitian

Tipe penelitian yang akan digunakan dalam penelitian ini adalah penelitian yuridis normatif, yakni metode yang dilakukan dengan cara meneliti bahan-bahan hukum kepustakaan. Penelitian ini juga ditunjang dengan melakukan wawancara kepada pihak-pihak yang bersangkutan.

2. Pendekatan Penelitian

Pendekatan penelitian adalah suatu metode atau cara dalam mengadakan penelitian. Pendekatan digunakan oleh Penulis untuk mendapatkan suatu informasi dari berbagai aspek mengenai isu yang sedang diteliti oleh Penulis. Dalam penelitian ini digunakan pendekatan Undang-undang (statute approach) dan pendekatan kasus (case approach). Pendekatan undangundang (statute approach) dilakukan dengan menelaah semua undang-

\footnotetext{
7) Peter Mahmud Marzuki, Penelitian Hukum. Edisi Revisi. (Jakarta: Kencana Prenada Media Group, 2009), hal.57.

8) Ibid., hal.3.

9) Ibid., hal.35.
} 
undang dan regulasi yang bersangkut paut dengan isu hukum yang sedang diteliti dan ditangani. ${ }^{10)}$

Melalui pendekatan undang-undang, Penulis akan mengetahui apabila ada konsistensi dan kesesuaian antara suatu Undang-undang dengan Undang-undang lainnya; atau antara Undang-undang dan Undang-undang Dasar; atau antara suatu regulasi dan Undang-undang. ${ }^{11)}$

3. Jenis Bahan Hukum

Jenis bahan hukum yang akan dipergunakan oleh Penulis dalam penelitian ini antara lain sebagai berikut:

a. Bahan Hukum

1) Bahan hukum primer yakni bahan hukum yang bersifat autoritatif, artinya memiliki otoritas. ${ }^{12)}$ Lebih lanjut bahan hukum primer dalam penelitian ini terdiri dari:

a) Undang-Undang Dasar Negara Republik Indonesia Tahun 1945;

b) Undang-Undang Nomor 5 Tahun 1960 tentang Peraturan Dasar Pokok-Pokok Agraria;

c) Peraturan Pemerintah Nomor 24 Tahun 1997 tentang Pendaftaran Tanah;

d) Peraturan Presiden Nomor 17 Tahun 2015 tentang Kementerian Agraria dan Tata Ruang;

e) Putusan Mahkamah Agung Republik Indonesia Nomor: 1537 K/Pdt/2018;

f) Putusan Pengadilan Tinggi Semarang Nomor: 345/Pdt/2017/PT SMG; dan

g) Putusan Pengadilan Negeri Purwodadi Nomor: 14/Pdt.G/2017/PN PWD.

\footnotetext{
10) Ibid., hal.133 .

11) Loc.Cit.

12) Ibid., hal.181.
} 
2) Bahan hukum sekunder yakni semua bahan publikasi tentang hukum yang merupakan dokumen yang tidak resmi. ${ }^{13}$ ) Publikasi yang dimaksud tersebut adalah publikasi mengenai hukum yang meliputi teks, kamus-kamus hukum, jurnal-jurnal hukum, dan komentarkomentar atas putusan pengadilan. ${ }^{14)}$ Lebih lanjut dalam penelitian ini bahan sekunder yang akan Penulis gunakan adalah buku-buku teks, kamus-kamus hukum, serta jurnal-jurnal hukum yang bersangkutan dengan pokok pembahasan.

3) Bahan hukum tersier yakni bahan-bahan hukum yang memberikan petunjuk serta penjelasan terhadap bahan hukum primer dan bahan hukum sekunder ${ }^{15)}$, lebih lanjut dalam penelitian ini bahan hukum tersier yang Penulis gunakan adalah Kamus Besar Bahasa Indonesia.

\section{b. Bahan Non-Hukum}

Bahan non-hukum dapat berupa buku-buku mengenai ilmu politik, ekonomi, sosiologi, filsafat, kebudayaan ataupun laporan-laporan penelitian non-hukum, dan jurnal-jurnal non-hukum sepanjang mempunyai relevansi dengan topik penelitian yang kemudian sebatas sebagai pelengkap. ${ }^{16)}$ Lebih lanjut dalam penelitian ini bahan non-hukum yang akan Penulis gunakan antara lain adalah buku-buku mengenai agraria dan pendaftaran tanah.

Bahan non-hukum juga dapat berupa hasil wawancara, dialog, kesaksian ahli hukum di pengadilan, seminar, ceramah, dan kuliah. ${ }^{17)}$

\footnotetext{
${ }^{13)}$ H. Zainuddin Ali, Metode Penelitian Hukum, (Jakarta: Sinar Grafika, 2009), hal.47.

14) Op.cit., hal.181.

15) Soerjono Soekanto dan Sri Mamudji, Penelitian Hukum Normatif Suatu Tinjauan Singkat, (Jakarta: Rajawali Press, 1983), hal.13.

16) Ibid., hal.183-184.

17) Ibid., hal.206.
} 
4. Spesifikasi Data

Spesifikasi data yang digunakan adalah deskriptif analisis yang mengungkapkan mengenai peraturan perundang-undangan yang terkait dengan teori-teori hukum yang menjadi objek penelitian. Penelitian hukum merupakan suatu kegiatan ilmiah yang didasarkan pada metode, sistematika dan pemikiran secara mendalam atas fakta hukum tersebut kemudian mengusahakan suatu pemecahan atas permasalahan-permasalahan yang timbul di dalam gejala yang bersangkutan.

5. Teknik Analisis Data

Metode analisis yang dipakai adalah menggunakan teknik analisis kualitatif dengan interaktif model yaitu komponen reduksi data dan penyajian data dilakukan bersama dengan pengumpulan data dengan metode pendekatan normatif yaitu metode yang dilakukan dengan cara meneliti bahan-bahan hukum kepustakaan.

\section{PEMBAHASAN}

Ketentuan mengenai pendaftaran tanah diatur dalam PP 24/1997 tentang Pendaftaran Tanah dan dalam PP 24/1997 ini menyebutkan bahwa instansi Pemerintah penyelenggara pendaftaran tanah di seluruh wilayah Republik Indonesia adalah BPN, dan tugas pelaksanaannya dibantu dan dilaksanakan oleh Kepala Kantor Pertanahan Kabupaten/ Kota. Menurut Prof. Boedi Harsono, pendaftaran tanah adalah suatu rangkaian kegiatan yang dilakukan oleh Negara/ Pemerintah secara terus menerus dan teratur yang berupa pengumpulan data mengenai tanah yang ada di suatu wilayah, pengolahan, penyimpanan, dan penyajiannya dalam rangka untuk memberikan jaminan kepastian hukum bagi kepentingan seluruh rakyat di bidang pertanahan, termasuk dalam hal penerbitan tanda bukti dan juga pemeliharaannya. Tujuan pendaftaran tanah menurut Pasal 30 Ayat (1) huruf a PP 24/1997 untuk pengumpulan dan penyajian informasi mengenai bidang-bidang tanah. 
Sistem pendaftaran tanah yaitu sistem pendaftaran hak, yang ditunjukkan dengan adanya buku tanah yang sebagai dokumen yang memuat data yuridis dan fisik serta dengan terbitnya sertipikat sebagai tanda bukti hak yang didaftarkan. Pasal 29 PP 24/1997 menyatakan pembukuan dalam buku tanah dan juga pencatatannya dalam surat ukur merupakan bukti bahwa hak yang bersangkutan beserta pemegang haknya dan bidang tanahnya yang diuraikan surat ukur secara hukum telah didaftar.

Sistem publikasi dalam penyelenggaraan pendaftaran tanah ada 2 yaitu sistem publikasi positif dan sistem publikasi negatif. Sistem publikasi yang digunakan dalam pendaftaran tanah di Indonesia yaitu sistem publikasi negatif yang juga mengandung unsur positif. Menurut Bapak Hanafi, dalam sistem publikasi positif, setiap bidang tanah yang sudah diterbitkan yang sudah diajukan haknya maka sertipikat itu menjadi mutlak, yaitu tidak dapat diganggu gugat dan tidak dapat dibatalkan. Sementara dalam stelsel publikasi negatif, sertipikat tanah merupakan tanda bukti yang kuat sepanjang data fisik dan data yuridisnya benar, tetapi bisa diajukan gugatan oleh pihak-pihak lain yang dapat membuktikan sebaliknya.

Menurut Bapak Hanafi, Rezim Hukum Pertanahan yang dipakai di Indonesia menganut stelsel negatif yang bertendesi ke positif. Hal tersebut sesuai menurut Prof. Boedi Harsono bahwa sistem publikasi yang digunakan dalam pendaftaran tanah di Indonesia yaitu sistem publikasi negatif yang juga mengandung unsur positif. Sistem ini menghasilkan surat-surat tanda bukti hak yang kemudian berlaku sebagai alat bukti yang kuat, sehingga bukan merupakan sistem publikasi positif maupun sistem publikasi negatif yang murni. Penulis setuju dengan pendapat tersebut sesuai dengan penjelasan Pasal 32 Ayat (2) PP 24/1997 yang menjelaskan pendaftaran tanah yang penyelenggaraannya oleh UUPA tidak menggunakan sistem publikasi positif yang kebenaran datanya disajikan oleh Negara, melainkan menggunakan sistem publikasi negatif yang tidak dijamin kebenaran data yang disajikan oleh Negara, tetapi juga tidak menggunakan sistem publikasi negatif murni. 
Kegiatan pendaftaran tanah untuk pertama kalinya menghasilkan surat tanda bukti hak berupa sertipikat tanah. Sertipikat dalam Pasal 32 Ayat (1) PP 24/1997 tentang Pendaftaran Tanah yaitu surat tanda bukti hak, yang berlaku sebagai alat bukti yang kuat mengenai data fisik dan data yuridis yang termuat didalamnya. Menurut Bapak Adrian Sutedi, sertipikat sebagai tanda bukti hak yang kuat mengandung pengertian bahwa data fisik dan data yuridis dalam suatu sertipikat mempunyai kekuatan bukti dan harus diterima sebagai suatu keterangan yang benar, selama tidak dibuktikan sebaliknya dengan alat bukti lain berupa sertipikat atau selain dari sertipikat (petuk pajak bumi/ kutipan letter $\mathrm{c}$ ).

Menurut Bapak Hartoyo selaku Kepala BPN Kabupaten Grobogan mengenai kasus yang terjadi di Kabupaten Grobogan, daerah Grobogan terdapat banyak tanah yang bersengketa.

Penulis dalam hal ini melakukan analisis mengenai penyelesaian atas sertipikat tanah ganda menurut PP 24/1997 dengan studi kasus yang diambil yaitu sertipikat tanah ganda yang diterbitkan oleh BPN Kabupaten Grobogan. Kasus tersebut telah diputus oleh Pengadilan Negeri Purwodadi dengan putusan Nomor: 14/Pdt.G/2017/PN PWD, kemudian diperkuat oleh putusan Pengadilan Tinggi Nomor: 345/Pdt/2017/PT SMG, dan sudah inkrah dengan putusan Mahkamah Agung Nomor: 1537 K/Pdt/2018. Penulis juga telah melakukan wawancara dengan Bapak Pri Pambudi Teguh selaku Hakim Ketua dalam Putusan PT Nomor: 345/Pdt/2017/PT SMG, Bapak Hartoyo selaku Kepala BPN Kabupaten Grobogan dan Bapak Hanafi Tanawijaya selaku Dosen Fakultas Hukum sekaligus Praktisi Hukum.

Dasar pertimbangan dari putusan PT Nomor: 345/Pdt/2017/PT SMG menyatakan bahwa segala sesuatu yang telah dipertimbangkan oleh PN Purwodadi dianggap benar maka dalam putusan PT ini hanya memperkuat putusan PN Purwodadi, dikarenakan pertimbangan di PN sudah benar maka di tingkat Banding, PT memperkuat. Pertimbangan PN yang dianggap benar yaitu tanah sengketa adalah milik Penggugat, 
yang dibeli dengan 2 ekor kerbau. Para Tergugat hanya menguasai, sedangkan menurut hibah dan sertipikat hak atas tanah, tanah tersebut adalah milik Penggugat. Para Tergugat melanggar ketentuan Pasal 24 Ayat (2) huruf a PP 24/1997 yaitu penguasaan hak atas tanah di tanah hak atas tanah milik orang lain dengan SHM No. 1270 atas nama Sabari Bin Sadi.

Dasar hukum dalam memutus perkara ini yaitu judex facti dari putusan PN, karena putusan PN ini dianggap tepat maka oleh PT diperkuat. Penggugat dapat membuktikan saat persidangan di PN Purwodadi, dengan adanya saksi-saksi membuktikan bahwa tanah tersebut milik Penggugat dan sudah bersertipikat. Oleh karena tanah sengketa bisa dibuktikan bahwa milik Penggugat, merupakan hasil jualbeli, hibah yang sah, maka tanah tersebut benar bahwa milik Penggugat. Klaim para Tergugat bahwa tanah tersebut milik mereka dan Penggugat hanya menumpang tidak dapat dibuktikan. Sertipikat yang diperoleh para Tergugat dengan cara yang tidak sah, sehingga oleh Pengadilan dinyatakan tidak mempunyai daya berlaku menurut hukum.

Dalam kasus ini, para pihak sama-sama mempunyai sertipikat tanah yang berupa SHM, dengan kata lain terjadi sertipikat tanah ganda dalam tanah tersebut. Berawal dari Penggugat bernama Subari yang memiliki tanah pekarangan hasil hibah dari orang tuanya (Sadi), yang berupa tanah sawah dan pekarangan yang dicatat dalam Kutipan C Desa, Desa Sumberagung Kecamatan Ngaringan Kabupaten Grobogan, yang berupa tanah sawah sesuai dengan Nomor C Desa 1412, atas nama Praptoredjo Soebari, Persil Nomor 97, Klas S IV, Luas $3100 \mathrm{~m} 2$, sedangkan tanah pekarangan sesuai dengan Nomor C Desa 1412, atas nama Praptoredjo Soebari, Persil 80 b, Klas D I, Luas 1.200 m2, dan tanah tegalan sesuai dengan Nomor C Desa 1412, atas nama Praptoredjo Soebari, Persil 80 c, Klas D III, Luas 3.350 m2. Kemudian tanah pekarangan sesuai dengan Nomor C Desa 1412, atas nama Praptoredjo Soebari, Persil 80 b, Klas D I, Luas 1.200 m2, yang terletak di Dusun Nongko RT 006 RW 009 Desa Sumberagung Kecamatan Ngaringan Kabupaten Grobogan menjadi SHM dengan Nomor 1270 atas 
nama Sabari bin Sadi, dengan Nomor Warkah 423 W/1987 dengan Luas 4.600 m2, yang dikeluarkan oleh Kepala Kantor Agraria Kabupaten Grobogan dengan pembukuan pada tanggal 4 April 1987.

Penggugat juga memiliki tanah hasil dari pembeliannya dari Parmi (Alm) dengan 2 ekor kerbau. yang kemudian pada tanggal 27 Juni 1963, Parmi (Alm) membuat Surat Pernyataan Jual Beli terhadap sebidang tanah pekarangan milik Parmi (Alm) yang dijual kepada Penggugat, dan tanah pekarangan tersebut bersebelahan dengan tanah pekarangan milik Penggugat. Kemudian pada 1986, Penggugat mengajukan permohonan SHM ke Kantor Pertanahan Kabupaten Grobogan, yang diajukan melalui Pemerintah Desa Sumberagung Kecamatan Ngaringan Kabupaten Grobogan, tanah pekarangan hasil jual beli dari Parmi (Alm) dijadikan satu dengan tanah pekarangan milik Penggugat yang merupakan hibah dari orang tuanya. Tidak ada pihak-pihak yang keberatan termasuk Marto Kasmin (Alm) beserta keluarganya sehingga sah, dan terbitlah SHM dengan Nomor 1270 atas nama Sabari bin Sadi.

Pada tahun 1988, Marto Kasmin meninggal dunia yang pada saat iu meninggalkan 2 orang anak bawaannya yaitu Sanem dan Ngadimin. Sanem (Alm) menikah dengan Sakidin (Alm) dan mempunyai 6 orang anak yang 2 di antaranya bernama Mukhlisin (Tergugat I) dan Ngastun (Tergugat III) yang saat ini menguasai obyek sengketa dan sampai sekarang masih menempati tanah pekarangan milik Penggugat secara melawan hukum.

Tergugat I mempunyai anak bernama Nurul Huda (Tergugat IV) dan Ali Ansori (Tergugat V) yang saat ini juga ikut menguasai obyek sengketa. Tergugat III menikah dengan Waji (Tergugat II) mempunyai anak yang bernama Sri Widayati (Tergugat VI) dan Yasak (Tergugat VII) yang saat ini juga ikut menguasai obyek sengketa.

Pada awal tahun 2016, terjadi konflik antara Penggugat dan Tergugat IV. Tergugat IV mengklaim bahwa keseluruhan termasuk yang ditempati oleh Penggugat 
dan anak Penggugat adalah tanah milik Marto Kasmin (Alm) dan mengatakan bahwa Penggugat dianggap hanya menumpang saja sehingga mengakibatkan Penggugat merasa tersakiti padahal mereka yang telah bertahun-tahun menempati dan menikmati tanah yang merupakan hak milik Penggugat. Setelah konflik tersebut, Penggugat dengan didampingi oleh anak-anak Penggugat melaporkan kejadian tersebut kepada ketua RT setempat dan pemerintah Desa Sumberagung, Kecamatan Ngaringan, Kabupaten Grobogan, namun tidak ada tanggapan. Kemudian pada bulan Januari 2016, anak Penggugat ke Kantor BPN Kabupaten Grobogan, dengan tujuan untuk memperjelas status atas Hak Kepemilikan tanah dimaksud, namun SHM Nomor 1270 atas nama Sabari Bin Sadi ditahan selama 4 bulan oleh BPN Kabupaten Grobogan yang akhirnya diberikan setelah adanya bantuan hukum.

Pada tanggal 10 Juni 2016 diadakan mediasi di rumah Kepala Desa Sumberagung, Kecamatan Ngaringan, Kabupaten Grobogan. Penggugat menunjukkan alat bukti yang berupa fotokopi SHM dengan Nomor 1270 atas nama Sabari Bin Sadi, Nomor C Desa 1412, Persil 80 b, Klas D I, dengan Nomor Warkah 423 W/1987 dengan Luas: $4.600 \mathrm{~m} 2$, Surat Jual Beli antara Penggugat dengan Parmi (Alm), fotokopi Kutipan C Desa Nomor 1412 atas nama Praptoredjo Soebari. Tergugat I dan Tergugat II tidak menunjukkan alat bukti berupa SHM, namun menunjukkan kutipan C Desa yang ditunjukkan melalui Kepala Desa Sumberagung. Dengan telah diadakan mediasi tersebut, kemudian diterbitkan Surat Kesepakatan Bersama Penyelesaian Sengketa Kepemilikan Tanah (selanjutnya disebut dengan "Surat Kesepakatan"). Dalam Surat Kesepakatan Bersama tersebut termuat di dalamnya bahwa Penggugat dan Tergugat masing-masing memiliki hak atas tanah dimaksud, dan dilakukan pengukuran ulang yang dianggap Penggugat merupakan tindakan diskriminatif, hal pembodohan dan semata-mata timbul niat perampasan hak-hak Penggugat, serta adanya intervensi dan juga intimidasi dari pihak-pihak yang tidak bertanggung jawab dan membela salah satu Pihak, netralitas dalam pelaksanaan mediasi tidak terwujud, dan hasilnya Penggugat merasa dirugikan, di dzolimi dan di rampas haknya secara melawan hukum. 
Setelah diterbitkannya Surat Kesepakatan dicantumkan bahwasannya Marto Kasmin (Alm) telah memberikan hibah wasiat kepada Penggugat adalah isi kesepakatan bersama yang menyalahi hukum dikarenakan Penggugat tidak pernah menerima baik Hibah maupun Wasiat dari Marto Kasmin (Alm), sebagaimana tertera dalam Surat Kesepakatan, namun Penggugat beserta anak-anak Penggugat dipaksa untuk menandatangani Surat Kesepakatan tersebut. Sedangkan Para Tergugat telah diberi 3 (tiga) obyek tanah yang tertera dalam Letter C Desa Nomor 940 Tahun 1981, sebagaimana tertera dalam Surat Kesepakatan, serta dalam perjalanan penyelesaian sengketa Tergugat I terdapat perbedaan data dimana Keterangan Nomor Warkah berbeda dengan penunjuk Warkah dan tidak ada paraf sebagai bentuk ACC pada kolom tanda tangan Kepala Kantor Agraria dan Tergugat II menunjukan SHM No. 660 a/n Waji-Ngastun, artinya tanah tersebut diperoleh dari jual beli setelah Waji-Ngastun menikah, dengan adanya 2 hal tersebut nyata-nyata telah memanipulasi data, terjadi upaya merampas hak-hak Penggugat, dan hal tersebut merupakan hal yang disengaja telah melakukan Perbuatan Melawan Hukum (selanjutnya disingkat menjadi "PMH”) yang dilakukan secara berjamaah.

Pada tanggal 13 Juni 2016, dibuatkan Perjanjian Penyelesaian Sengketa oleh bagian sengketa sebagai Mediator Bersertifikat pada Kantor BPN Kabupaten Grobogan dengan No. 38/PPS/SKP/VI/2016 (yang selanjutnya disebut "Perjanjian Penyelesaian Sengketa sebagai Mediator Bersertifikat") yang kemudian diadakan pengukuran ulang oleh bagian sengketa sebagai Mediator Bersertifikat pada Kantor BPN kabupaten Grobogan adalah tidak dikehendaki oleh penggugat, hal tersebut merupakan tindakan yang merampas hak-hak Penggugat, hasil dari kegiatan pengukuran ulang yang dilakukan oleh bagian sengketa pada Kantor BPN Kabupaten Grobogan hasilnya selalu berubah-ubah yang dikonfirmasi oleh Anak Penggugat. Pihak bagian sengketa pada Kantor BPN Kabupaten Grobogan menyatakan bahwa hal tersebut salah ketik dan terhadap Perjanjian Penyelesaian Sengketa oleh BPN Kabupaten Grobogan tanpa adanya tanda tangan Kepala BPN Grobogan dan stempel BPN Kabupaten Grobogan. 
Pada tanggal 18 Februari 2017, Penggugat yang melalui Kuasa Hukumnya telah mengajukan Surat Permohonan Fasilitator Mediasi kepada Pemerintah Desa Sumberagung dengan Nomor 48/LBH-CB/P/II/2017 dan Surat Permohonan Kesediaan Mediasi kepada Para Tergugat dengan Nomor 49LBH-CB/P/II/2017 dengan maksud agar Pemerintah Desa Sumberagung menjadi Fasilitator Mediasi terhadap perkara dimaksud dan Para Tergugat bersedia diajak mediasi. Terhadap hal tersebut telah dilaksanakan oleh Pemerintah Desa Sumberagung, namun Para Tergugat semuanya tidak bersedia dan tetap berpegang pada Surat Kesepakatan tanggal 10 Juni 2016 dan Perjanjian Penyelesaian Sengketa sebagai Mediator Bersertifikat tanggal 13 Juni 2016 yang tata cara dan isinya bertentangan dengan hukum dan kenyataan yang sebenarnya. Penguasaan hak atas tanah oleh Para Tergugat yang merupakan SHM No. 1270 atas nama Sabari Bin Sadi merupakan pelanggaran terhadap ketentuan PP No. 24/1997 tentang Pendaftaran Tanah Pasal 24 Ayat (2) huruf a yang menyatakan bahwa penguasaan tersebut dilakukan dengan itikad baik dan secara terbuka oleh pihak yang bersangkutan sebagai yang berhak atas tanah serta diperkuat oleh kesaksian orang yang dapat dipercaya karena penguasaan obyek sengketa oleh Para Tergugat telah melakukan PMH.

Setelah menempuh berbagai cara, Penggugat akhirnya mengajukan gugatan ke Pengadilan Negeri Purwodadi dengan hasil putusan Nomor: 14/Pdt.G/2017/PN Pwd yang mengabulkan gugatan Penggugat untuk sebagian. Selain itu isi putusannya yaitu menyatakan objek sengketa adalah milik Penggugat, menyatakan penguasaan para Tergugat I sampai dengan VII atas objek sengketa adalah PMH, memerintahkan agar objek sengketa tersebut diserahkan kepada Penggugat, menyatakan bahwa SHM Nomor 651 dan 650 tidak mempunyai daya berlaku menurut hukum, Surat Kesepakatan Bersama Penyelesaian Sengketa yang dibuat di bawah tangan pada 10 Juni 2016 adalah batal demi hukum, perjanjian penyelesaian sengketa (perdamaian) nomor: 38/PPS/SKP/VI/2016 tertanggal 13 Juni 2016 yang dikeluarkan oleh Kantor BPN Kabupaten Grobogan batal demi hukum, kemudian menghukum Turut Tergugat untuk 
tunduk pada Putusan, dan menghukum Tergugat secara tanggung renteng untuk membayar biaya perkara yang timbul dalam perkara tersebut.

Tergugat 1 sampai dengan 7 dan Turut Tergugat 2 yaitu BPN yang selanjutnya disebut sebagai Pembanding 1 sampai dengan Pembanding 8 mengajukan banding ke Pengadilan Tinggi Semarang dan Subari yang semula Penggugat selanjutnya disebut sebagai Terbanding dan Pemerintahan Desa Sumberagung, Kecamatan Ngaringan, Kabupaen Grobogan, selanjutnya sebagai Turut Terbanding. Hasil putusan Pengadilan Tinggi Semarang Nomor: 345/Pdt/2017/PT SMG ini yaitu menguatkan putusan Pengadilan Negeri Nomor: 14/Pdt.G/2017/PN Pwd tanggal 4 Mei 2017 yang dimohon banding tersebut.

BPN Kabupaten Grobogan sebagai Pemohon Kasasi I bersama dengan Tergugat I sampai dengan VII yang selanjutnya disebut sebagai Para Pemohon Kasasi mengajukan kasasi ke Mahkamah Agung. Penggugat dalam kasasi ini sebagai Termohon Kasasi. Pemerintahan Desa Sumberagung, Kecamatan Ngaringan, Kabupaten Grobogan sebagai Turut Termohon Kasasi. Mahkamah Agung telah memberikan putusan yang inkrah mengenai kasus tersebut dengan Putusan Nomor: 1537 K/Pdt/2018. Hasil putusan Nomor: 1537 K/Pdt/2018 yaitu menolak permohonan tingkat kasasi dari Pemohon Kasasi dan Para Pemohon Kasasi.

Menurut hasil wawancara dengan Kepala BPN Kabupaten Grobogan, sertipikat tanah dapat dibagi menjadi 2 yaitu sertipikat ganda dan sertipikat tumpang tindih. Sertipikat ganda yang berarti dalam satu bidang tanah terdapat 1 sertipikat, kemudian diterbitkan sertipikat lagi. Sertipikat tumpang tindih yaitu tanah yang telah diukur sebelumnya kemudian diukur lagi pada alas yang berbeda. Menurut hasil wawancara dengan Bapak Hanafi, sertipikat tanah ganda artinya satu bidang tanah yang terdapat 2 sertipikat tanah di atasnya (overlapse). 
Menurut Bapak Hanafi, sertipikat tanah ganda terjadi kemungkinan besar karena adanya kesalahan administratif atau kesalahan pengukuran. Menurut Kepala BPN Kabupaten Grobogan, sertipikat ganda sendiri sering terjadi dikarenakan dilakukan secara manual dan pengarsipan warkahnya tidak dilaksanakan dengan baik, serta terdapat kemungkinan adanya salah satu pihak yang beritikad tidak baik. Penulis setuju dengan pendapat kedua narasumber yang pada intinya sertipikat tanah ganda kemungkinan besar dapat terjadi disebabkan karena adanya maladministrasi di awal.

Namun dalam pendaftaran tanah, Kepala BPN Kabupaten Grobogan menjelaskan bahwa hal yang masih rancu dalam masyarakat sebenarnya adalah BPN tidak menetapkan tanda batas. BPN tidak dapat mengukur apabila tidak ditunjukkan oleh pemohon dan harus dipasang tanda batas oleh yang bersangkutan, serta terdapat saksi yang memperhatikan yang dikenal dengan asas contradictoire delimitatie. Penulis setuju dengan pendapat tersebut karena sesuai dengan Pasal 17 PP 24/1997 yang mempunyai maksud yaitu pemegang hak atas tanah yang bersangkutan wajib melakukan penempatan tanda-tanda batas termasuk pemeliharaannya sehingga menurut Penulis sertipikat tanah ganda sendiri apabila terjadi dikarenakan perrmasalahan tanda batas yang tidak benar, disebabkan karena keteledoran atau itikad tidak baik dari salah satu pihak yang bersengketa.

Mengenai sertipikat tanah ganda, Kepala BPN Kabupaten Grobogan menyatakan bahwa BPN menganggap semua sertipikat adalah benar. Dengan kata lain, apabila terjadi sertipikat ganda, BPN tidak dapat mengatakan sertipikat mana yang benar dan sertipikat mana yang tidak benar sehingga untuk penyelesaian sertipikat tanah ganda harus dibuktikan di Pengadilan. Hal tersebut juga dikemukakan oleh Bapak Hanafi sesuai dengan pengaturan dalam PP 24/1997. Penyelesaian atas sertipikat tanah ganda harus diselesaikan melalui pengadilan. Menurut Bapak Pri Pambudi, dalam hal pembuktian di persidangan alat bukti yang dapat digunakan yaitu alat bukti tertulis, 
saksi, dan juga alat bukti penunjuk, serta yang biasanya menjadi pertimbangan dalam menyelesaikan sengketa sertipikat tanah ganda yaitu:

1. Pertama, sertipikat yang mana yang diterbitkan terlebih dahulu.

2. Kedua, sertipikat yang mana yang prosedurnya benar.

3. Ketiga, mana yang beritikad baik, maksudnya penjual memang orang yang berhak, pembeli sudah mengecek terlebih dahulu tanah tersebut ada sengketa atau tidak.

Namun pertimbangan-pertimbangan tersebut tidak mutlak, dalam hal ini Pengadilan harus menilai satu per satu, kasus per kasus, dilihat dengan sungguhsungguh mana yang terbit lebih dahulu, dengan itikad baik, dan prosedurnya benar.

Pada putusan Pengadilan Purwodadi Nomor: 14/Pdt.G/2017/PN Pwd tercantum frasa bahwa "Kantor Pertanahan Kabupaten Grobogan kompetensinya hanya sebagai "Instansi Registrasi Recht", bukan penentu kebenaran materi. Penulis setuju dengan frasa tersebut karena seperti hasil wawancara dengan narasumber Kepala BPN Kabupaten Grobogan yang menyatakan BPN tidak dapat langsung membatalkan karena yang dapat memutuskan sah atau tidak sahnya sertipikat tanah adalah Pengadilan, sehingga memang harus diselesaikan di Pengadilan.

BPN dalam hal sengketa sertipikat tanah ganda sebagai Turut Tergugat. Kemudian BPN sebagai Turut Tergugat harus patuh terhadap hasil putusan Pengadilan yang sudah inkrah. Dengan kata lain, ketika suatu putusan sudah inkrah, BPN dapat membatalkan sertipikat yang kalah. Pembatalan sertipikat tersebut tergantung pada pihak yang kalah tersebut, karena belum ada pengaturan mengenai batas jangka waktu untuk pembatalan. Menurut Bapak Hartoyo selaku Kepala BPN Kabupaten Grobogan, baiknya dari Pengadilan memberikan jangka waktu dan menegaskan untuk dilakukan dengan itikad baik atau apabila dengan itikad tidak baik pun sertipikat tanah yang dimilikinya akan dengan sendirinya mati. Dalam hal ini Penulis setuju dengan pendapat 
Kepala BPN Kabupaten Grobogan, dikarenakan dengan belum adanya penegasan mengenai batas jangka waktu sehingga pihak yang kalah tidak merasa jera.

Berdasarkan analisis Penulis dari hasil wawancara dengan Bapak Hanafi selaku Dosen Fakultas Hukum dan juga Praktisi Hukum, putusan pengadilan sendiri harus memberikan kepastian hukum sehinga tidak mungkin dalam sengketa sertipikat tanah ganda, kedua sertipikat tanah tersebut dibenarkan. Hal ini dikarenakan hakim harus memutus yang paling benar dan paling berhak atas bukti-bukti yang telah diajukan, saksi-saksi, dokumen-dokumen yang merupakan bagian dari peradilan yang umum

Selain itu, berdasarkan analisis Penulis dari hasil wawancara dengan Bapak Hartoyo selaku Kepala BPN Kabupaten Grobogan, kemungkinan untuk terjadinya sertipikat tanah ganda saat ini adalah tidak mungkin melihat dari sistem yang digunakan BPN dengan inovasi baru yaitu sistem aplikasi KKP. Dalam sistem aplikasi KKP ini, peta-peta bidang diukur secara elektronik dan secara keseluruhan. Selain itu, terdapat nomor seri yang akan menunjukkan kepemilikkan seseorang yang akan terdaftar bahwa kepemilikkan suatu bidang tanah tersebut adalah milik seseorang tersebut dan dapat diketahui di mana letak sertipikat tanah tersebut. Dengan adanya sistem aplikasi KKP yang ada saat ini, dapat diketahui apabila peta bidang yang memiliki letak yang sama saling bersinggungan maka tidak dapat diterbitkan sertipikat lagi untuk bidang tersebut sehingga tidak dapat diajukan lagi pendaftaran tanah untuk bidang itu. KKP dilaksanakan salah satunya untuk menghindari persengketaan batas.

Penulis setuju dengan adanya sistem aplikasi KKP saat ini, karena sesuai dengan Peraturan Menteri ATR/ Kepala BPN RI No. 23 Tahun 2016 tentang Pembentukan Kantor Layanan Pertanahan Bersama dan Pelimpahan Kewenangan Pengesahan Catatan pada Buku Tanah Elektronik yang Tervalidasi dan Penandatangan Sertifikat Hak Atas Tanah dalam Rangka Kegiatan Pendaftaran Tanah Tertentu pada Kantor Layanan Pertanahan Bersama Terintegrasi (selanjutnya disingkat menjadi "Permen ATR/ Kepala BPN RI 23/2016"). Permen ATR/ Kepala BPN RI 23/2016 ini sebagai 
peraturan pelaksana PP 24/1997 dalam rangka memberikan kemudahan dan mendekatkan diri kepada masyarakat serta peningkatan pelayanan dan lebih proaktif kepada masyarakat. Selain lebih praktis untuk digunakan masyarakat, juga memberikan kepastian hukum bagi masyarakat sehingga tidak adanya kemungkinan terjadi sertipikat tanah ganda di kemudian hari dan menghindari pihak yang beritikad tidak baik.

\section{PENUTUP}

\section{A. Kesimpulan}

Berdasarkan pembahasan yang telah diuraikan oleh Penulis sebelumnya, maka Penulis menarik kesimpulan secara umum, bahwa sertipikat merupakan alat bukti yang kuat yang dijadikan sebagai pegangan bagi pemilik hak atas tanah untuk mendapat kepastian hukum mengenai dasar kepemilikkan hak atas tanahnya. Sertipikat tanah sebagai hasil dari pendaftaran tanah. Pendaftaran tanah di Indonesia diselenggarakan oleh BPN, dinyatakan secara tegas dalam ketentuan PP 24/1997, dan dibantu oleh Kepala Kantor Pertanahan Kabupaten/Kota dalam hal pelaksanaannya.

Sertipikat tanah ganda yaitu dalam suatu tanah terdapat 2 sertipikat hak atas tanah yang sama. Sengketa sertipikat tanah ganda dapat terjadi dikarenakan kesalahan administrasi yang dilakukan oleh BPN, misalnya dalam hal pengukuran, pengarsipan warkahnya, dan dilakukan secara manual, dan juga dapat terjadi karena adanya itikad tidak baik dari salah satu pihak.

Berdasarkan kasus posisi yang telah diterangkan dalam bab-bab sebelumnya, kasus yang Penulis ambil yaitu Putusan Mahkamah Agung Nomor: 1537 K/Pdt/2018. Dari kasus yang Penulis analisis, dalam sengketa sertipikat ganda yang terjadi ini terdapat salah satu pihak yang beritikad tidak baik dengan melanggar ketentuan Pasal 24 Ayat (2) huruf a PP 24/1997 yaitu penguasaan hak atas tanah di tanah hak atas tanah milik orang lain dengan SHM No. 1270 atas 
nama Sabari Bin Sadi. Penyelesaian atas sertipikat tanah ganda dalam Putusan Mahkamah Agung Nomor: 1537 K/Pdt/2018 juga telah dilaksanakan dengan membatalkan sertipikat milik Tergugat yang tidak mempunyai bukti-bukti yang kuat mengenai kepemilikkan tanah tersebut.

Penyelesaian atas sertipikat tanah ganda menurut PP 24/1997 dapat dilakukan melalui Pengadilan, untuk mendapatkan kepastian hukum bahwa sertipikat kepemilikkan hak atas tanah yang mana yang mempunyai pembuktian lebih kuat didasarkan pada alat-alat bukti yang sesuai dengan ketentuan PP 24/1997. Apabila pihak yang dikalahkan di tingkat Pengadilan Negeri tidak menerima hasil putusan Pengadilan Negeri, maka dapat mengajukan Banding di tingkat Pengadilan Tinggi, bahkan mengajukan Kasasi di tingkat Mahkamah Agung untuk mendapat kepastian hukum dengan putusan yang lebih inkrah.

Selain penyelesaian atas sertipikat tanah ganda dilakukan melalui Pengadilan, terdapat pula Peraturan Kepala BPN Nomor 3 Tahun 2011 tentang Pengkajian dan Penanganan Kasus Pertahanan, serta Peraturan Menteri Agraria dan Tata Ruang/ Kepala Badan Pertanahan Nasional Republik Indonesia Nomor 11 Tahun 2016 tentang Penyelesaian Kasus Pertanahan sehingga instrumeninstrumen ini dapat digunakan apabila dirasa terjadinya maladministrasi, maka Kepala BPN dapat membatalkan.

Berdasarkan analisis yang Penulis lakukan pada bab-bab sebelumnya, saat ini terdapat suatu sistem aplikasi yang telah diatur dalam peraturan pelaksana dari PP 24/1997 yaitu Permen ATR/ Kepala BPN RI 23/2016. Permen ATR/ Kepala BPN RI 23/2016 mengatur adanya sistem aplikasi bernama KKP untuk membantu masyarakat dalam hal pendaftaran tanah. Dengan adanya sistem aplikasi KKP ini, tidak ada kemungkinan dalam suatu letak tanah terdapat 2 kepemilikkan sertipikat hak atas tanah yang sama. Hal ini dikarenakan peta-peta bidang diukur secara elektronik secara keseluruhan dengan aplikasi KKP ini dan juga pada sertipikat tanah yang diterbitkan terdapat nomor seri sehingga dapat 
diketahui bahwa suatu sertipikat tanah tersebut adalah milik siapa dan diterbitkan di mana. Selain itu, sistem aplikasi KKP ini memberikan kepastian hukum bagi masyarakat sehingga menghindari adanya pihak yang beritikad tidak baik terhadap suatu bidang tanah.

\section{B. Saran}

Setelah Penulis memberikan kesimpulan seperti yang telah diuraikan di atas, maka berikut ini Penulis akan memberikan saran sebagai berikut:

1. Bagi masyarakat, bahwa agar masyarakat paham mengenai penyelesaian atas sertipikat tanah ganda yang ada di Indonesia untuk menjamin kepastian hukum bagi masyarakat sendiri. Penyelesaian atas sertipikat tanah ganda menurut PP 24/1997 dapat dilakukan melalui Pengadilan dan peraturanperaturan yang berlaku. Selain itu, masyarakat disarankan untuk lebih meningkatkan kesadaran hukum seperti mengetahui adanya inovasi baru yaitu sistem KKP yang merupakan wujud dari pelaksanaan PP 24/1997 yang memudahkan masyarakat dalam hal pendaftaran tanah maupun pemeliharaan data.

2. Bagi Pemerintah, agar lebih berhati-hati dalam menyelenggarakan pendaftaran tanah dan juga untuk mensosialisasikan mengenai sistem baru yang merupakan wujud pelaksanaan PP 24/1997 yaitu KKP sesuai dengan tujuannya yaitu dalam rangka memudahkan dan meningkatkan pelayanan bagi masyarakat sehingga dapat menjamin kepastian hukum kepada masyarakat secara keseluruhan.

\section{DAFTAR PUSTAKA}

\section{A. Buku}

Ali, H. Zainuddin. Metode Penelitian Hukum. (Jakarta: Sinar Grafika, 2009). 
Harsono, Boedi. Hukum Agraria Indonesia: Sejarah Pembentukan UndangUndang Pokok Agraria, Isi, dan Pelaksanaannya. Cetakan ke-8. (Jakarta: Trisakti, 2018).

Harsono, Budi. Hukum Agraria Indonesia (Himpunan Peraturan-Peraturan Hukum Tanah). Cetakan Ke-15. (Jakarta: Djambatan, 2002).

Hutagalung, Arie S. Tebaran Pemikiran Seputar Masalah Hukum Tanah. (Jakarta: Lembaga Pemberdayaan Hukum Indonesia, 2005).

Marzuki, Peter Mahmud. Penelitian Hukum. Edisi Revisi. (Jakarta: Kencana Prenada Media Group, 2009).

Santoso, Urip. Pendaftaran dan Peralihan Hak atas Tanah. Cetakan ke-1. (Jakarta: Kencana, 2010).

Soekanto, Soerjono. Pengantar Penelitian Hukum. (Jakarta: Universitas Indonesia, 1986).

Soekanto, Soerjono dan Sri Mamudji. Penelitian Hukum Normatif Suatu Tinjauan Singkat. (Jakarta: Rajawali Press, 1983).

\section{B. Peraturan Perundang-Undangan}

Undang-Undang Dasar Negara Republik Indonesia Tahun 1945

Undang-Undang Nomor 5 Tahun 1960 Tentang Peraturan Dasar Pokok-Pokok Agraria ((Lembaran Negara Republik Indonesia Tahun 1960 Nomor 104, Tambahan Lembaran Negara Republik Indonesia Nomor 2043)

Peraturan Pemerintah Nomor 24 Tahun 1997 Tentang Pendaftaran Tanah (Lembaran Negara Republik Indonesia Tahun 1997 Nomor 59, Tambahan Lembaran Negara Republik Indonesia Nomor 3696)

Peraturan Presiden Nomor 17 Tahun 2015 tentang Kementerian Agraria dan Tata Ruang (Lembaran Negara Republik Indonesia Tahun 2015 Nomor 18) 